\title{
Yeni Türk Ticaret Kanunu ve Kurumsal Yönetim Uygulamaları Sonrası İç Denetimin Gelişen Rolü: Türkiye'de İç Denetçilerin Algısı Araştırması*
}

\author{
The Evolving Role of Internal Auditing After the New Turkish \\ Commercial Code and Corporate Governance Applications: Research of \\ Perceptions of Internal Auditors in Turkey
}

\author{
Yrd. Doç. Dr. Burak Özdoğan - Prof. Dr. Semra Öncü
}

\section{Öz}

Çalışma ile Yeni Türk Ticaret Kanunu'nun iç denetim mesleğine yönelik etkileri ve kanun sonrası iç denetim birimlerinin kurumsal yönetim kültürünün yerleşmesine yönelik sunabileceği katkılar tartışılmıştır. Çalışmanın araştırma kısmında ise iç denetçilerin yasa sonrası mesleğin durumuna ilişkin algıların ortaya koyma amacıyla gerçekleştirilen anket bulgu ve değerlendirmeleri paylaşılmıştır.

Sonuç olarak, iç denetçilerin Yeni Türk Ticaret Kanunu sonrası iç denetim birimlerine yüklenen sorumluluğun farkında ve bu sorumluluğu üstlenmeye hazır oldu$\breve{g} u$, ayrica Türkiye'deki birçok işletme için en önemli gelişim alanlarından biri olan kurumsal yönetim gibi konularda, iç denetçilerin çok önemli katkıları bulunabileceği ortaya konmuştur.

Anahtar Kelimeler: $\dot{I}_{c ̧}$ Denetim, Yeni Türk Ticaret Kanunu, Kurumsal Yönetim, İç Denetçi

\section{Abstract \\ This study, argues the effects of New Turkish Commer- cial Code to internal auditing profession and contri- butions of internal auditing departments to establish corporate governance culture after the New Turkish Commercial Code. Perceptions of internal auditors}

about the current position of the profession after the New Turkish Commercial Code has been shown at the research section of the study.

The results of the research has showed that internal auditors in Turkey are aware of and ready to take the responsibilities that comes from the New Turkish Commercial Code. Also it has been seen that internal auditors may have important contributions on many of important development fields in businesses such as corporate governance.

Keywords: Internal Auditing, New Turkish Commercial Code, Corporate Governance, Internal Auditor

\section{Giriş}

Küreselleşmenin ve serbest ticaretin nimetlerinden olabildiğince yüksek seviyede faydalanmayı amaçlayan ve sadece kara odaklanan işletmelerin denetim ve gözetiminde yaşanan eksiklikler, küresel çapta skandallar ve beraberinde gelen krizlerle sonuçlanmıştır. 2000 'li yıllara damgasinı vuran muhasebe temelli skandallar tüm dünyayı etkilemiş ve gerek düzenleyici kurumların gerekse de işletme paydaşlarının farkındalık düzeyinin artmasını mecburen de olsa sağ-

Yrd. Doç. Dr. Burak Özdoğan, Celal Bayar Üniversitesi İİF, burak.ozdogan@cbu.edu.tr

Prof. Dr. Semra Öncü, Celal Bayar Üniversitesi İ̈BF, semra.oncu@cbu.edu.tr

* Bu makale, Arş. Gör. Dr. Burak Özdoğan’ın “İç Denetçilerin Gelişen İç Denetim Uygulamalarına ve Paydaş Beklentilerine Uyumu” adlı doktora tezinden üretilmiştir. Bu tez çalışması Celal Bayar Üniversitesi Bilimsel Araştırma Projeleri Tarafından desteklenmiştir. Proje No: 2013-076 
lamıştır. 2002 yılında Amerika'da çıkarılan Sarbanes Oxley Yasası ile başlayan düzenleme akımını dünyanın birçok ülkesi takip etmiş ve yasal düzenlemeler eliyle, işletmelerin sahip olduğu zayıf denetim yapısını revize ederek kaybolan güven ortamının yeniden tesis edilmesi amaçlanmıştır. Bu farkındalığın diğer ayağında bulunan şirket hissedarları, yatırımcıları ve diğer tüm paydaş grupları da kendilerine güvence sağlayacak bir dayanağın işletme içerisinde oluşturulmasına yönelik adımlar atılmasını desteklemişlerdir.

Türkiye, hızla gelişmekte olan ekonomisi, henüz kurumsallaşma sürecinin erken evrelerinde bulunan ve profesyonel yönetim kültürünün yeni yerleşmeye başladığı işletmeleri ile gelişmiş ülkelerin yaşadı$\breve{g}_{1}$ skandallar ve sonrası süreçlerden ders çıkararak benzer olayları yaşamadan önlem alma avantajına sahiptir. Yeni Türk Ticaret Kanunu (TTK) bu açıdan değerlendirildiğinde, son 50 yılda yapılan en önemli düzenleme olarak görülmektedir. Bu düzenleme ile kurumsal yönetime dair önemli adımlar atılmış, daha modern yönetim yapılarının işletmelere yerleşebilmesi için yol gösterici bir rehber rolü üstlenilmiştir. İç denetim de yasa içerisinde yer alan doğrudan ve dolaylı maddeler ile bu dönüşümün önemli bir parçası olarak değerlendirilmektedir. İç denetim birimlerinin Türkiye'deki işletmeler içerisinde yer alması ve denetim komiteleri gibi üst yapılar ile desteklenmesi, hem kurumsal yönetim açısından hem de işletme paydaşlarının hak ve çıkarlarının korunması açısından önem arz etmektedir. Bu noktada gerçekleştirilen yasal düzenlemelerin işletmelere başarılı bir şekilde uygulanabilmesi ve hedeflenen amaçlara ulaşabilmesi için iç denetçilerin kendilerinden beklenen rolleri iyi anlaması ve uygulayabilecek yeterlilikte olması gerekmektedir.

TTK, kurumsal yönetim ilkelerinden denetim komitesine, muhasebe standartlarından iç denetime önemli düzenlemeleri kapsamaktadır. Genel olarak TTK içerisindeki iç denetime yönelik düzenlemeler, uluslararası uygulamalarla paralellik arz etmektedir.

\section{İç Denetim Perspektifinden Kurumsal Yönetim}

Kurumsal yönetim; bir şirketin, hak sahipleri ve kamuoyunun menfaatlerine zarar vermeyecek biçimde, finansal kaynakları ve insan kaynaklarını kendine çekmesini, verimli çalışmasını ve bu sayede hissedar- ları için uzun dönemde ekonomik kazanç yaratarak istikrar sağlamasını mümkün kılan kanun, yönetmelik ve ilgili gönüllü özel sektör uygulamalarının bileşimidir (TKYD ${ }^{1}$ ve Delloite, 2006, s.4).

Bir başka tanımlama ile kurumsal yönetim, "işletmenin stratejik yönetimi ve yönlendirmesi ile görevli ve sorumlu üst yönetimin (söz sahipleri), bu görevlerin ve sorumluluklarını yerine getirirken işletme üzerinde kendilerini belirli nedenlerle "hak sahibi" gören pay sahipleri, çalışanları, tedarikçi, müşteri ve diğer toplumsal kurumlarla olan ilişkilerini kapsamaktadir" (Ülgen ve Mirze, 2010, s.461).

Ekonomik İşbirliği ve Kalkınma Örgütü (OECD), kurumsal yönetimi şu şekilde tanımlamaktadır: "Kurumsal yönetim, bir şirketin yönetimi, yönetim kurulu, hissedarları ve diğer paydaşlar arasındaki bir dizi ilişkiyi kapsar. Kurumsal yönetim aynı zamanda, şirketin hedeflerinin belirlendiği bir yapıyı ortaya koymakta ve bu hedeflere nasıl ulaşılacağının ve performansın nasıl denetleneceğinin yollarını çizmektedir. İyi kurumsal yönetim, yönetim kurulları ve tepe yönetim için şirketin ve hissedarlarının çıarları doğrultusunda hedeflere yönelme açısından uygun teşvikleri sağlamalı ve etkin denetimi kolaylaştırmalıdır" (TKYD, 2005, s.9). Kurumsal yönetimin dünya çapında uygulanabilirliğini artırmak ve örgütler tarafından kurumsal yönetimin kurum içi entegrasyonunda yol gösterici olmak amaciyla OECD tarafindan kurumsal yönetim ilkeleri yayımlanmıştır. Uygulaması zorunlu olmayan ancak tüm dünyada kabul gören ilkeler beş başlıktan oluşmaktadır (OECD, 2004):

- Hissedar hakları

- Hissedarların adil muamele görmesi

- Kurumsal yönetimde doğrudan çıar sahiplerinin rolü

- Kamuoyuna açılkama yapma ve şeffaflık

- Yönetim kurulunun sorumlulukları

OECD tarafından yayımlanan kurumsal yönetim ilkelerinin yanı sıra, Türkiyede halka açı şirketlerde kurumsal yönetim anlayışının geliştirilebilmesi adına SPK tarafından da kurumsal yönetim ilkeleri yayımlanmış ve bir kurumsal yönetim endeksi oluşturularak kurumsal yönetim ilkelerini uygulayan şirketlerin bu endekste yer alması sağlanmıştır (SPK, 2005).

1 TKYD (Türkiye Kurumsal Yönetim Derneği) 
Kurumsal yönetim uygulamaları, şirketlerin içinde bulundukları ülkenin yasal düzenlemelerinden ve şirketin kendine has özelliklerinden dolayı farklılıklar gösterse de, tüm kurumsal yönetim modellerinde göz önünde bulundurulması gereken temel ilkeler vardır. Bu ilkeler; şeffaflık, hesap verebilirlik, adillik ve sorumluluk olarak sayılabilir (Doğan, 2007, s.50).

Şeffaflık, şirketlerin kamuoyu ile gerçekleştirdikleri bilgi paylaşımlarını doğru, açık, şeffaf ve zamanlı olarak yapması gerektiğini belirtmektedir. Hesap verebilirlik ilkesi bakımından ise şirketin kurumsal yönetim çerçevesinin, şirketin stratejik rehberliğini, yönetim kurulu tarafından gerçekleştirilecek yönetsel denetimin etkinliğini ve yönetim kurulunun, şirkete ve hissedarlara karşı hesap verme yükümlülügünü barındırması gerekmektedir. Adillik ilkesi, azınlık hissedarlar ve diğer ortaklar da dahil olmak üzere tüm hak sahiplerine karşı şirket yönetiminin eşit ve adil davranmasını ifade etmektedir. Sorumluluk ilkesi ise, şirketlerin hissedarları için değer yaratırken, toplum yararını da gözetmesi ve ilgili kanun ve düzenlemelere uyumlu faaliyet göstermesini ifade etmektedir (KYBP $\left.{ }^{2}, 2012\right)$.

Kurumsal yönetim, etkin bir iç denetim fonksiyonunun işletme içerisinde faaliyet gösterebilmesi için önemli bir anlayış biçimidir. Kurumsal yönetimin tüm ilkelerinin doğru biçimde işletmeye entegre edilmesi, iç denetim biriminin çalışma alanını rahatlatacak ve bağımsız biçimde görev yapmasını sağlayabilecektir. Diğer yandan ise iç denetim biriminin varlığı ve etkinliği, işletme içerisinde kurumsal yönetim kültürünün yayılmasına destek olarak işletme paydaşlarının çıkarları açısından bir güvence unsuru olarak görev üstlenebilecektir.

\section{Iç Denetim Perspektifinden Yeni Türk Ticaret Kanunu}

Özel yürürlük tarihleri bakımından ise 2012 yılından başlayarak 2014 yılına kadar uzanan bir takvimi bulunan yeni kanun ile şirketlerin yanı sıra doğrudan ve dolaylı yollardan birçok kurum, kuruluş ve meslek mensupları da kanundan etkilenen kesimler arasinda yer almıştır.

TTK'da birçok konunun yanı sıra iç denetim mesleği ve iç denetçilerin şirket içerisindeki rollerine ilişkin

2 KYBP (Kurumsal Yönetim Bilgi Platformu) ciddi sonuç ve değişimler doğuran maddeler bulunmaktadır. TTK’nın iç denetime ilişkin getirdiği doğrudan ve dolaylı düzenlemeler 366/2, 375 ve 378 nolu maddeler olarak tespit edilmiştir.

İlgili maddelerin içeriği şu şekildedir (İDM, 2012):

i. Madde 366/2: Yönetim kurulu; işlerin gidişini izlemek, kendisine sunulacak konularda rapor hazırlamak, kararlarını uygulatmak veya iç denetim amacıyla içlerinde yönetim kurulu üyelerinin de bulunabileceği komiteler ve komisyonlar kurabilir.

ii. Madde 375: Yönetim kurulunun devredilemez ve vazgeçilemez görev ve yetkileri şunlardır:

a. Muhasebe, finans denetimi ve şirketin yönetiminin gerektirdiği ölçüde, finansal planlama için gerekli düzenin kurulması.

b. Yönetimle görevli kişilerin, özellikle kanunlara, esas sözleşmeye, iç yönergelere ve yönetim kurulunun yazılı talimatlarına uygun hareket edip etmediklerinin üst gözetimi.

iii. Madde 378: Pay senetleri borsada işlem gören şirketlerde, yönetim kurulu, şirketin varllğını, gelişmesini ve devamını tehlikeye düşüren sebeplerin erken teşhisi, bunun için gerekli önlemler ile çarelerin uygulanması ve riskin yönetilmesi amaciyla, uzman bir komite kurmak, sistemi çalıştırmak ve geliştirmekle yükümlüdür. Diğer şirketlerde bu komite, denetçinin gerekli görüp bunu yönetim kuruluna yazılı olarak bildirmesi halinde derhal kurulur ve ilk raporunu kurulmasını izleyen bir ayın sonunda verir.

Uzun (2011, s.13), yeni kanunun iç denetimle ilişkili yukarıda belirtilen hükümlerinden çıkarılabilecek sonuçların şu şekilde olduğunu ifade etmiştir:

- Yönetim kurulunun iç denetim amaciyla içlerinde yönetim kurulu üyelerinin de bulunabileceği komite ve komisyonlar kurabilir hükmü, bankalar ve halka açık şirketler için zorunlu olan "denetim komitesi”nin tüm şirketler için kurulabileceğini göstermektedir.

- Denetim komitesi, yönetim kurulu adına şirketin iç denetim ve iç kontrol fonksiyonlarının 
etkinliğini ve yeterliliğini takip ederek kamuya açıklanacak finansal tabloların doğruluğu ve gerçekleri yansıttığına dair yönetim kuruluna görüş vermekte, bağımsız denetim firmasının seçilmesi ve faaliyetlerinin düzenli olarak izlenmesi gibi görevleri yerine getirmektedir. Denetim komitesinin etkin bir şekilde çalışması, ancak iç denetim biriminin yardımı ile olabilmektedir. $\mathrm{Bu}$ nedenle şirketlerde iç denetim faaliyetinin başlatılması yönetim kurulu için vazgeçilmez bir görev haline gelmiştir.

- Yönetim kurulunun devredilemez ve vazgeçilemez görev ve yetkilerini düzenleyen kanunun 375. Madde hükümleri ve gerekçelerinden de anlaşılacağı üzere, Yeni Türk Ticaret Kanunu ile birlikte şirket yönetim kurullarının modern ve etkili bir iç denetim fonksiyonuna olan ihtiyaçları ortaya çımakta, uluslararası standartlarda bir iç denetim faaliyetinin başlatılması gerekli hale gelmektedir.

TTK’nın kurumsal yönetim açısından getirdiği ciddi yenilikler bulunmaktadır. Önceki bölümde kısaca açıklanan kurumsal yönetim ilkeleriyle doğrudan ve dolaylı olarak örtüşen birçok düzenleme TTK içerisindeki yerini almıştır. Kurumsal yönetim ilkelerinden şeffaflık ile örtüşecek şekilde, TTK ile birlikte şirket kuruluşlarında, kuruculardan kuruluş işlemlerine ilişkin yazılı beyan istenmekte ve bu beyan ticaret sicil dosyasına konularak sicil müdürlügünnce saklanmaktadır. Yasa ${ }^{3}$ ile birlikte isteyen herkesin, ticaret sicilinin içeriğini inceleme ve onaylı suretini almasına imkan tanınmıştır. Ayrıca pay sahipleriyle ilgili olarak yapılan düzenleme ${ }^{4}$ neticesinde, pay sahibine oldukça kapsamlı bilgi alma ve inceleme hakkı tanınmıştır. İlaveten yasa ${ }^{5}$ ile; bağımsız denetçi, iç denetçi veya riskin erken saptanması ve yönetim komitesi hile veya dolandırıcılığa yönelik bir görüş bildirmiş ise her bir pay sahibinin özel denetçi talep edebilmesine izin verilmiştir.

Yasa sonrasında, kurumsal yönetime ilişkin genel bilgilerin verildiği başlık altında değinilen kurumsal yönetimin temel ilkeleri ile ilişkilendirilerek yorumlanabilecek değişimler yaşanmıştır.

Adillik ilkesi ile ilişkili olarak TTK incelendiğinde ise ilk olarak 357. madde dikkat çekmektedir. Madde ile

3 TTK 2. Kisım Madde 35.

4 TTK 2. Kisım Madde 200.

5 TTK 2. Kısım Madde 207. şirket birimlerinin öznel ve keyfi karar almalarının önüne geçilmiştir. Madde aracıllğ̆ıla esas sözleşme hükümlerinin adil ve eşit bir biçimde uygulanabilmesi sağlanmaktadır. Yine adillik ilkesi altında değerlendirilebilecek bir diğer yenilik de 358. madde ile getirilen pay sahiplerine şirketten borçlanma yasağıdır. Böylece pay sahiplerinin şirketle iş ilişkilerinde eşitlik ilkesi temel alınmıştır.

TTK’nın iç denetim ile ilişkisi açıklanırken belirtilen 375. madde, kurumsal yönetim açısından da şeffaflık ve hesap verebilirlik ilkeleriyle doğrudan örtüşen bir düzenlemedir. Ayrıca yine yasada yer alan yönetim kurulu üyeleriyle denetçilerin genel kurula katılma zorunluluğu, hesap verebilirlik ilkesi bakımından oldukça önemli bir adım olarak gösterilebilir.

Güreli (2011, s.8), TTK’nın kurumsal yönetim aç1sından getirdiği önemli yenilik ve yükümlülükleri şu şekilde özetlemiştir:

- Tüm yönetim komiteleri ve organlarında profesyonellik ve uzmanlık ön plana çıkartılmıştır.

- İmtiyazlı paylar sınırlandırılmıştır.

- Azınlık hakları listesi genişletilerek kuvvetlendirilmiş, yönetim kurulunda pay sahipleri toplulukları ile azınlık temsil olanakları zenginleştirilmiştir.

- Hukuki mekanizmaların kolay işlerliğinin sağlanması vasitasıla, pay sahiplerine tanınan aktif ve pasif bilgi alma, inceleme talebinde bulunabilme ve dava açabilme hakları artırılmıştır.

- Halka açık şirketlere kurumsal yönetim raporu yayımlamak zorunluluğu getirilmiştir.

- Sermaye Piyasası Kurulu, kurumsal yönetim ilkeleri ve uygulama çerçevesini belirlemede tek yetkili olarak belirlenmiştir.

\section{Türkiye'de İç Denetçilerin Yeni Türk Ticaret Kanunu ve Kurumsal Yönetim Uygulama- larına Yönelik Algıları Araştırması}

Araştırma ile TTK kapsamında iç denetime yüklenen sorumluluklar ile iç denetçilerin bu sorumluluklara yönelik algılarını ve yeterlilik düzeylerini araştırmak amaçlanmıştır. Araştırmanın kapsamı içinde Türkiye'de faaliyet göstermekte olan iç denetim mesleği mensuplarının TTK ile birlikte mesleğin geçire- 
ceği dönüşüme yönelik bakış açıları ve yasa ile yüklenen yeni rol ve sorumluluklara ilişkin hazırlıklar düzeyleri inceleme konusu yapılmıştır. Bu araştırma, gerek katılımcı sayısı gerekse de araştırma bulgularının doğrudan sektör temsilcilerinin katılımı yoluyla elde edilmesi sebebiyle Türkiye’de iç denetim mesleği ve literatürü için önem arz etmektedir. Araştırma ile ortaya konan bulguların ve sonuçların, bu alanda gerçekleştirilecek gelecek çalışmalar için de yol gösterici olması beklenmektedir.

\section{Literatür Taraması}

Yasanın işletmeler üzerindeki etkileri yeni ortaya çıkmaya başladığından dolayı bu alandaki literatür de henüz gelişim aşamasındadır. Kanun henüz tasarı halinde iken ve kanunun çıkışından sonra, farklı açılardan kanunu ve etkilerini ele alan kisitlı sayıda da olsa çalışmalar bulunmaktadır. TTK sonrasında şirketlerin yönetim kurulları, yapısal ve işlevsel açıdan yeni düzenlemelere kavuşmuştur. Kanundan kaynak$l_{1}$ bu değişimin temelinde kurumsal yönetim ilkeleri bulunmaktadır (Karaege, 2012). TTK sonrasinda kurumsal yönetim ve iç denetim konuları, kanunun doğrudan etkilediği alanlar olarak ele alınmıștır (Açıkalın, 2011; Hatunoğlu ve Güneş, 2012; İbiş ve Çatıkkaş, 2012, Özerhan ve Nazlığlu, 2012).

Açıkalın (2011), kurumsal yönetim ile ilgili çerçeve oluşturan maddelerin Yeni Türk Ticaret Kanunu’nun içine dahil edilmesine yönelik gerekçenin, ABD'deki Sarbanes Oxley yasasından sonra ortaya çıkan gelişmeler olduğunu belirtmiştir. Özerhan ve Nazlığlu (2012), çalışmaları ile Yeni Türk Ticaret Kanunu’nda kurumsal yönetim ilkelerine yönelik gerçekleştirilen finansal raporlama ve denetim odakl düzenlemelere ilişkin değerlendirmelerde bulunmuşlardır. İbiş ve Çatıkkaş (2012), TTK sonrasında, işletmelerde iç kontrol sisteminin genel durumunu ortaya koymay1 amaçlamışlardır. Hatunoğlu ve Güneş (2012) ise, TTK sonrasında kurumsal yönetim uygulamalarının muhasebe bilgi sistemine etkisini irdelemişlerdir.

Yeni Türk Ticaret Kanunu ve iç denetim mesleğine yönelik tartışmalar ise hem tasarı aşamasında hem de yasalaşma sonrasında devam etmiştir (Eşkazan, 2005; Cömert, 2008; Arıkan, 2010). Cömert (2008), çalışması ile kanun henüz tasarı halindeyken, getirilecek düzenlemelerin ișletmenin iç denetim birimlerine yönelik etkilerinin neler olabileceğini tartışmış ve sonuç olarak tasarının kurumsallaşmaya yönelik yararlı olacağını belirterek, denetim komitelerinin yapısı ve görevine ilişsin önerilerde bulunmuştur. Öz ve Yağdır (2012), çalışmalarında TTK sonrası iç denetim birimlerinin Uluslararası Finansal Raporlama Standartları (UFRS) ile uyuma yönelik katkıda bulunabileceğini ve UFRS uygulamalarına iç denetçilerin de dahil edilmesi gerektiğini belirtmiştir. Eşkazan (2005) ise, yasal düzenlemelerin hayata geçirilmesinin yanı sıra kurumsal yönetim anlayışı çerçevesinde şirketlerin iç kontrol sorumluluklarını herhangi bir zorunluluk olmaksızın yerine getirmesi gerektiğini belirtmiştir.

\section{Araştırmanın Yöntemi}

Araştırmada veri toplama yöntemi olarak anket uygulaması gerçekleştirilmiştir. Anket soruları; Uluslararası İç Denetçiler Enstitüsü tarafından gerçekleştirilen küresel anket çalışmasından (Bailey, 2010) ve aynı çalışma içerisinde yer verilen paydaş beklentileri anket çalışmasından (Bolger, 2010), E\&Y tarafından gerçekleştirilen iç denetimin geleceğine yönelik anket çalışmasından (E\&Y, 2012), PWC tarafından gerçekleştirilen iç denetimin geleceğine yönelik anket çalışmalarından (PWC, 2012a; PWC, 2012b) ve son olarak, Uluslararası İç Denetçiler Enstitüsü tarafından yaptırılan küresel anket çalışmasından (Holzinger, 2013) yararlanılarak hazırlanmıştır.

Anket, özel sektör şirketlerinde faaliyet gösteren denetim birimi yöneticileri ve iç denetçilere uygulanmıştır. Uygulama için, Türkiye genelinde toplam 1500 iç denetçiden oluşan bir veri tabanı, linkedin.com adlı profesyonel sosyal ağda yer alan iç denetçilerden oluşturulmuş ve tek tek aramalar yapılmıştır. CATI yöntemi ile anket formlarının uygulanması sonucunda toplamda 406 meslek mensubunun cevapları alınmış ancak dört adet anket formu eksik yanitlardan dolayı değerlendirme kapsamına alınmayarak araştırma ile ilgili toplam 402 anket değerlendirilmiştir. Yanıtları değerlendirmeye alınan 402 meslek mensubunun \%57'si 30-39 yas aralığında ve \%61'i mesleklerinin ilk 5 yılı içerisinde yer almaktadır. Katılımcıların \%69'u halka kapalı işletmelerde faaliyet göstermektedir. Son olarak ankete katılan iç denetçilerin \%65’i denetim komitesi bulunan işletmelerde çalışmaktadır.

Anket formu 9 bölüm ve toplam 43 sorudan oluşmaktadır. Bu çalışmanın konusu gereği uygulanan anketin TTK ve kurumsal yönetime ilişkin değişkenlerin yer aldığı ilk iki bölüm inceleme konusu yapılmıștır. Anket formunda yer alan ilgili bölümlere ilişkin Cronbach's Alpha katsayıları ise aşağıdaki Tablo 1'de görüldügü üzere 0,8 'in üzerindedir. Bu katsayı, ölçeğin yüksek derece güvenilir olduğunu belirtmektedir. 
Tablo 1. Ankette Yer Alan Değişkenlerin Cronbach's Alpha Güvenilirlik Analizi Sonuçları

\begin{tabular}{|ll|}
\hline Değişkenler & Alfa \\
& Katsayısı \\
& $(\boldsymbol{\alpha})$ \\
Yeni Türk Ticaret Kanunu ile İlgili Değişkenler & .81 \\
Kurumsal Yönetim ile İlgili Değişkenler & .83 \\
\hline
\end{tabular}

\section{Araştırma Bulguları ve Değerlendirmeler TTK'nın İç Denetim Mesleğine Yönelik Katkılarına iliş̧kin Bulgular}

TTK’nın iç denetim mesleğine yönelik katkılarına ilişkin meslek mensuplarının bakış açısını ortaya koymak üzere tasarlanan bu bölümde, beş soruya yönelik çalışmaya katılan iç denetçilerin yanıtları alınmıştır. Bölüme ilişkin bulgulara dair genel bir değerlendirme yapıldığında, katılımcıların çok yüksek bir pay ile bölümde yer alan önermelere katıldıkları anlaşılmaktadır. Bu bölümdeki soruların hiçbirine "kesinlikle katılmıyorum" cevabı veren katılımcı bulunmamaktadir.

Anket bölümüne ilişkin yanıtlar daha detaylı incelendiğinde ise; TTK sonrası iç denetimin yönetsel hesap verebilirliğin gelişmesine katkı sağlayacağı önermesine kesinlikle katılıyorum ve katılıyorum șeklinde yanıt veren katılımcıların oranı Tablo 2'de görüldüğü üzere toplamda \%93,5 olarak ölçülmüştür.

Tablo 2. Yeni TTK ile Iç Denetim, Yönetsel Hesap Verebilirliğin Gelişmesine Katkı Sağlayacaktır

\begin{tabular}{|l|l|l|l|}
\hline & Sıklık & Yüzde & Toplam Yüzde \\
\hline Kesinlikle katılıyorum & 66 & 16.4 & 16.4 \\
\hline Kat1lyorum & 310 & 77.1 & 93.5 \\
\hline Ne katılıyorum ne katılmıyorum & 17 & 4.2 & 97.8 \\
\hline Kat1lmiyorum & 9 & 2.2 & 100.0 \\
\hline Toplam & 402 & 100.0 & \\
\hline
\end{tabular}

Tablo 3 incelendiğinde, TTK sonrasında iç denetimin kurumsal devamlılık ve itibarı arttırarak işletme amaçlarını gerçekleştirmesine yardımcı olacağ şeklinde görüş bildiren meslek mensuplarının oranı \%95,7 olarak ölçülürken bu görüşe katılmayanların oranı ise \%1'de kalmıştır.

Tablo 3. Yeni TTK ile Iç Denetim, İşletmenin Kurumsal Devamııı̆ı̆ ve Itibarııı Arttırarak Amaçlarını Gerçekleştirmesine Yardımcı Olacaktır

\begin{tabular}{|l|l|l|l|}
\hline & Siklık & Yüzde & Toplam Yüzde \\
\hline Kesinlikle katılıyorum & 81 & 20.1 & 20.1 \\
\hline Katıliyorum & 304 & 75.6 & 95.8 \\
\hline Ne katıliyorum ne katılmıorum & 13 & 3.2 & 99.0 \\
\hline Katılmiyorum & 4 & 1.0 & 100.0 \\
\hline Toplam & 402 & 100.0 & \\
\hline
\end{tabular}


TTK ile, iç denetimin hata ve hilelerin önlenmesine yönelik iç kontrol sisteminin geliştirilmesindeki rolünün önemli olacağı görüşünü destekleyen anket katılımcılarının oranı \%94,5 olarak ölçülmüştür. Bu görüșe katılmayan iç denetçiler ise \% 1,5 gibi oldukça düşük bir paya sahip olarak Tablo 4’te görülmektedir.

Tablo 4. Yeni TTK ile iç Denetim, Hata ve Hilelerin Önlenmesini Sağlamak için Şirket Yöneticilerince Tasarlanan Iç Kontrol Sisteminin Geliştirilmesinde Önemli Rol Üstlenir

\begin{tabular}{|l|l|l|l|}
\hline & Frek. & Yüzde & Küm. Yüzde \\
\hline Kesinlikle katılıyorum & 66 & 16.4 & 16.4 \\
\hline Kat1lyorum & 314 & 78.1 & 94.5 \\
\hline Ne katılıyorum ne katılmıyorum & 16 & 4.0 & 98.5 \\
\hline Katılmıyorum & 6 & 1.5 & 100.0 \\
\hline Toplam & 402 & 100.0 & \\
\hline
\end{tabular}

TTK ile birlikte iç denetimin, işletmenin karşılaştığ risklerin yönetimine ve risklerin ortaya çıkarılmasına yönelik olarak katkıda bulunacağı, işletmenin risk kaynaklı olası zararlarını önlemesini sağlayacağ yönünde görüş bildiren katılımcıların toplam oranı
\%93,1 olarak ölçülmüștür. Tablo 5’te detayları görüldüğü üzere iç denetçilerin sadece $\% 1,7$ 'si bu görüşe katılmadıkları şeklinde görüş bildirmiştir. Katılımc1lar içerisinde kesinlikle katılmadı̆̆ını belirten bulunmamaktadır.

Tablo 5. Yeni TTK ile İ̧ Denetim, Şirketlerin Karşı Karşıya Kaldığı Riskleri Bilmesi, ölçmesi, Değerlendirmesi ve Yönetebilmesini Sağlayarak Mümkü̈n Olabilecek Çeşitli Risklerden Kaynaklanan Zararların Önlenmesini Sağlar

\begin{tabular}{|l|l|l|l|}
\hline & Frek. & Yüzde & Küm. Yüzde \\
\hline Kesinlikle katılıyorum & 67 & 16.7 & 16.7 \\
\hline Kat1lyyorum & 307 & 76.4 & 93.1 \\
\hline Ne kat1liyorum ne katılmıyorum & 21 & 5.2 & 98.3 \\
\hline Kat1lmiyorum & 7 & 1.7 & 100.0 \\
\hline Toplam & 402 & 100.0 & \\
\hline
\end{tabular}

Tablo 6. Yeni TTK ile İ̧ Denetim, Şirketin Bağımsız Denetime Hazır OImasına Önemli Katkı Sağlar

\begin{tabular}{|l|l|l|l|}
\hline & Frek. & Yüzde & Küm. Yüzde \\
\hline Kesinlikle kat1lyyorum & 77 & 19.2 & 19.2 \\
\hline Kat1lyorum & 294 & 73.1 & 92.3 \\
\hline Ne kat1liyorum ne katılmiyorum & 25 & 6.2 & 98.5 \\
\hline Kat1lmiyorum & 6 & 1.5 & 100.0 \\
\hline Toplam & 402 & 100.0 & \\
\hline
\end{tabular}


TTK ile, iç denetimin şirketi bağımsız denetime hazırlamasına önemli katkı sağlayacağ 1 görüşüne katılan iç denetçilerin oranı \%92,3 olarak ölçülmüştür. Katılmıyorum şeklinde cevap veren iç denetçilerin oranı ise \%6'da kalmıştır.

\section{TTK Sonrası İç Denetimin Kurumsal Yönetime Katkılarına Yönelik Bulgular}

TTK sonrasında işletmede kurumsal yönetim anlayışının geliştirilmesine yönelik iç denetimin sağlayacağı katkılara ilişkin olarak çalışmaya katılan meslek mensuplarının bakış açılarını ortaya çıkarmak üzere toplam dört sorudan oluşan bir bölüm hazırlanmıştır. Bölüme ilişkin bulgular bütün olarak değerlendirildiğinde, bir önceki bölüme benzer şekilde, meslek mensuplarının büyük bir çoğunluğu ölçekte yer alan kurumsal yönetime ilişkin iç denetimin katkı önermelerine katıldıklarını belirtmişlerdir.

Daha detaylı olarak bulgular incelendiğinde, TTK sonrası kurumsal yönetim açısında iç denetimin, denetim komiteleri aracılığıyla katkısının önemli olacağ 1 şeklinde görüş bildiren iç denetçilerin oranı $\% 89,8$ olarak Tablo 7'de görülmektedir. Bu oran içerisinde \%16,4'lük pay, kesinlikle katılıyorum şeklinde görüş bildiren meslek mensuplarını temsil etmektedir. Katılmıyorum olarak görüş bildiren iç denetçilerin oranı ise \%3,5 olarak ölçülmüştür. Kesinlikle katılmıyorum şeklinde görüş bildiren katılımcı bulunmamaktadır.

Tablo 7. Yeni TTK ile Kurumsal Yönetim Açısından Iç Denetim, Denetim Komiteleri Aracılığıyla Kurumsal Yönetime Önemli Katkı Sağlar

\begin{tabular}{|l|l|l|l|}
\hline & Frek. & Yüzde & Küm. Yüzde \\
\hline Kesinlikle kat1liyorum & 66 & 16.4 & 16.4 \\
\hline Kat1lyorum & 295 & 73.4 & 89.8 \\
\hline Ne kat1lyyorum ne katılmiyorum & 27 & 6.7 & 96.5 \\
\hline Kat1lmiyorum & 14 & 3.5 & 100.0 \\
\hline Toplam & 402 & 100.0 & \\
\hline
\end{tabular}

Kurumsal yönetime katkı açısından TTK ile birlikte iç denetimin, denetim komiteleri ile birlikte hata ve yolsuzlukların önlenmesine katkı sağlayacağına kesinlikle katılıyorum ve katılıyorum olarak yanıt veren iç denetçilerin toplam oran $1 \% 85,8$ olarak ölçülmüştür. Yine Tablo 8'deki bulgular dikkate alındığında, katılmıyorum şeklinde görüş bildirenlerin oranı ise $\% 5,2$ olarak tespit edilmiştir.

Tablo 8. Yeni TTK ile Kurumsal Yönetim Açısından Iç Denetim, Denetim Komiteleri ile Birlikte Şirkette Hata ve Yolsuzlukları Önler

\begin{tabular}{|l|l|l|l|}
\hline & Frek. & Yüzde & Küm. Yüzde \\
\hline Kesinlikle kat1liyorum & 52 & 12.9 & 12.9 \\
\hline Kat1lyorum & 293 & 72.9 & 85.8 \\
\hline Ne kat1lıyorum ne katılmiyorum & 36 & 9.0 & 94.8 \\
\hline Kat1lmiyorum & 21 & 5.2 & 100.0 \\
\hline Toplam & 402 & 100.0 & \\
\hline
\end{tabular}


TTK ile birlikte kurumsal yönetim açısından değerlendirildiğinde iç denetimin, üst yönetimin icraatlarına yönelik kontrol ve denge rolleri üstlenerek kurumsal yönetimin gelişmesine katkı sağlayacağı önermesini destekleyen meslek mensuplarının toplam oranı \%91 olarak ölçülürken bu görüşe katılmayan iç denetçiler \%10’luk bir paya sahip olarak ölçülmüştür.

Tablo 9. Yeni TTK ile Kurumsal Yönetim Açısından İ̧ Denetim, Yönetim Kurulu ve Üst Yönetim için Kontrol ve Denge Rolünü Üstlenerek Kurumsal Yönetime Katkı Sağlar

\begin{tabular}{|l|l|l|l|}
\hline & Frek. & Yüzde & Küm. Yüzde \\
\hline Kesinlikle kat1lıyorum & 60 & 14.9 & 14.9 \\
\hline Kat1lyorum & 306 & 76.1 & 91.0 \\
\hline Ne kat1liyorum ne kat1lmiyorum & 26 & 6.5 & 97.5 \\
\hline Kat1lmiyorum & 10 & 2.5 & 100.0 \\
\hline Toplam & 402 & 100.0 & \\
\hline
\end{tabular}

Tablo 10. Yeni TTK ile Kurumsal Yönetim Açısından Iç Denetim, Kurumsal Yönetimin İşletme Içcerisinde Benimsenmesine ve Yerleşmesine Yönelik Önemli Roller Üstlenmiştir

\begin{tabular}{|l|l|l|l|}
\hline & Frek. & Yüzde & Küm. Yüzde \\
\hline Kesinlikle kat1lyyorum & 58 & 14.4 & 14.4 \\
\hline Kat1lyyorum & 307 & 76.4 & 90.8 \\
\hline Ne kat1liyorum ne katılmiyorum & 28 & 7.0 & 97.8 \\
\hline Kat1lmiyorum & 9 & 2.2 & 100.0 \\
\hline Toplam & 402 & 100.0 & \\
\hline
\end{tabular}

İç denetimin, kurumsal yönetimin şirket içerisinde benimsenmesi ve yerleşmesinde, TTK ile birlikte önemli roller üstleneceği şeklindeki görüşe katıldığını belirten toplam iç denetçi oranı \%90,8 olarak ölçülmüştür.

\section{TTK'nın İ̧̧ Denetime Katkıları ve Kurumsal Yönetime ilişkin Bulguların Değerlendirmesi}

Türk Ticaret Kanunu’na ilişkin tasarının ortaya çımasından itibaren, kanun değişikliğinden doğrudan ve dolaylı olarak etkilenen tüm paydaşlar, ilgili kurum ve kuruluşlar aracılığıyla eleştiri ve önerilerini belirterek taslağın son halini almasına ve yasalaşmasına katkıda bulunmuşlardır. Yasa sonrasında yine ilgili paydaş temsilcileri, yasadaki değişimler neticesinde kendi çevrelerine ilişkin olası olumlu ve olumsuz etkilere yönelik görüşlerini beyan etmişlerdir.
Türkiye İç Denetim Enstitüsü (TİDE) de bu amaç ile sürecin başından itibaren aktif bir şekilde fikir beyan eden yapilardan biri olmuştur. Türkiye'de iç denetim mesleğine ilişkin, uluslararası kabul gören tek çatı kuruluş olarak faaliyet gösteren TiDE'nin, yasanın iç denetim mesleğine yönelik katkılarına ilişkin olarak 2012 yılında yayımladığ 1 bildiriyi temel alarak, meslek mensuplarının konuya ilişkin bakış açısını ortaya çıkarmayı amaçlayan bir anket çalışması, meslek mensuplarına gerçekleştirilmiş ve bulgular önceki bölümlerde paylaşılmıştır.

Bulgular ışığında değerlendirme yapıldığında, Türkiye'de faaliyet gösteren iç denetim mesleği mensupları, Türk Ticaret Kanunu’nun mesleğin gelişimine yönelik olarak katkısını, gerek ülke çapında mes- 
leğin farkındalığı açısından gerekse de işletme içerisindeki öneminin vurgulanması açısından önemli olarak görmektedir. İç denetim mesleğini doğrudan ve dolaylı olarak etkileyen maddelerin TTK ile hayata geçmesi sonrasında, iç denetim birimlerinin kurum içerisindeki rol ve sorumluluklarının giderek arttığ ve bu birimin sunabileceği katkıların işletme yönetimlerince farkına varıldığı yönünde iç denetim mesleği mensuplarının ortak görüşe sahip oldukları, Şekil l'de görülen çalışma bulgularından anlaşılmaktadır.

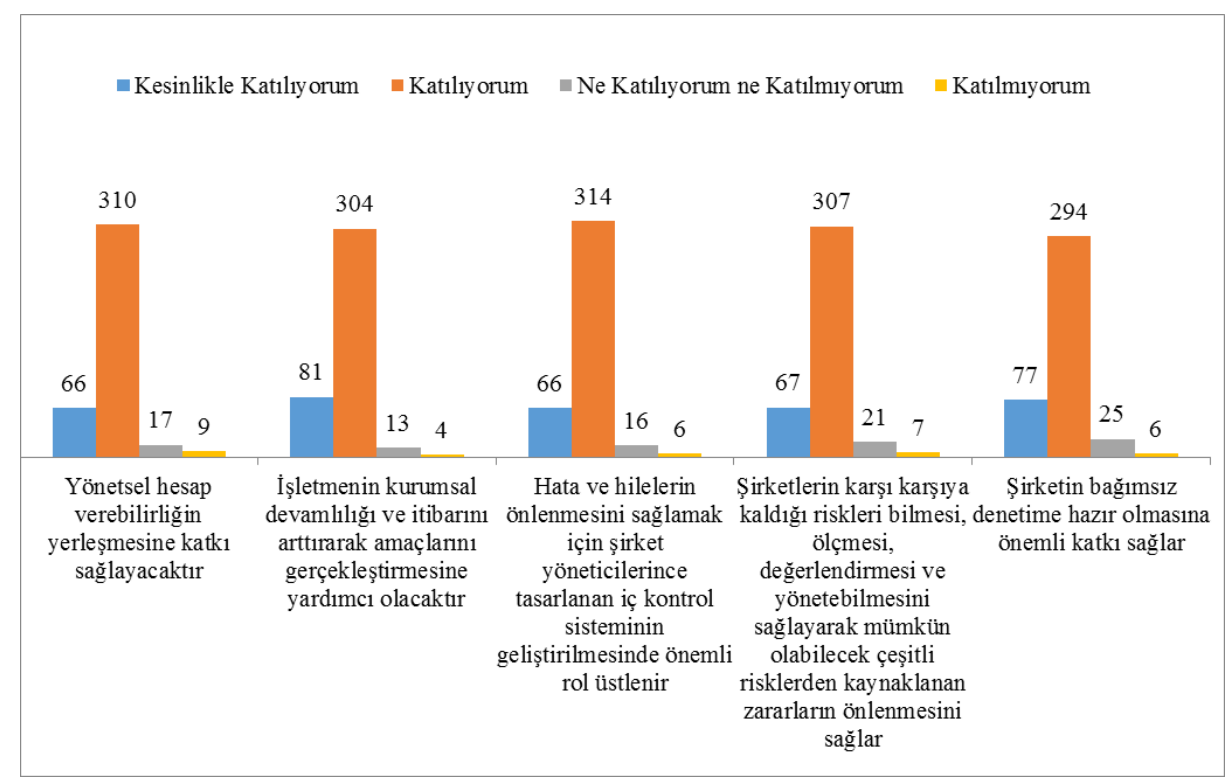

Şekil 1. TTK ile IIIgili Anket Bölümünün Genel Görüntüsü

TTK’nın önceki bölümlerde açıklanan maddelerinden biri olan madde 375 , yönetim kurulunun vazgeçilemez ve devredilemez yetkileri arasında muhasebe ve finans denetimine yer vermektedir. Bu görevi yerine getirebilmesi için, yönetim kurulunun en önemli destekçisi, kurum içerisinde yer alan iç denetim birimi olacaktır. Ankete katılan iç denetçilerin \%90’ından fazlası bu görüşü destekleyerek, yönetimin hesap verme yükümlülügüne yönelik olarak görevlerin kurum içerisinde yerleşmesine iç denetimin katkı sağlayacağını belirtmişlerdir. TTK'nın şirketlere sağlamak istediği en önemli katkılardan biri de ilgili maddeler eliyle kurumsal itibarın arttırılması olarak görülmektedir.

Kurumsal itibarın sağlanabilmesinin yolu şeffaflık ve doğruluktan geçmektedir. Bu noktada iç denetim birimleri, kurum içerisinde yürütülen faaliyetlerin doğruluğuna ilişkin büyük bir sorumluluk üstlenerek hesap verebilirliğin geliştirilmesini sağlayacaktır.
Çalışma sonuçlarına göre, Türkiye'de iç denetçilerin $\% 95$ in üzerinde bir oranla bu görüsse katıllyor olması işletme yönetimleri için önemli bir destek oluşturmaktadır.

TTK'nın getirdiği bir zorunluluk olarak ve zorunlu olmasının yanı sıra işletmelerin ve paydaşlarının haklarının korunması açısından da çok önemli bir mekanizma olan iç kontrol sisteminin geliştirilmesi gerekmektedir. Bu noktada da kurumlar içerisinde yer alan iç denetçiler, sahip oldukları bilgi birikimi ve tecrübeleri itibariyle, iç kontrol sisteminin gelişimine önemli katkılarda bulunabileceklerdir. İşletme içerisinde iç kontrol sistemi mevcut ise, zayıf yönlerini tespit etmek ve iyileştirmek, işletme içerisinde iç kontrol sistemi yok ise, sistemin tasarımına destek olmak iç denetim biriminin görevi olacaktır. Anket bulgularından, Türkiye'de iç denetçilerin bu görev ve sorumluluğun bilincinde oldukları anlaşılmaktadır. 
Anket çalışmasının bulguları açık bir şekilde göstermektedir ki; Türk Ticaret Kanunu kapsamında ortaya çıkan yenilenme ve iyileştirme ortamına, Türkiye'de faaliyet gösteren iç denetçilerin önemli katkıları bulunabilecektir. Türk Ticaret Kanunu'nun TIDDE tarafından öngörülen mesleğe yönelik getirilerine iç denetçiler de çok büyük bir oranda katılım göstermektedir.

TTK ile birlikte iç denetim ve kurumsal yönetime yönelik gelişmeler paralellik izlemektedir. İlgili kanun maddeleri her iki alanı birbirinden ayrılmaz bir bütün haline getirmektedir.

TTK'nın 378. maddesi bu ilişkiye bir örnek olarak, borsada işlem gören halka açık işletmeler için risklerin erken teşhisi ve yönetilmesi amacıyla bir komite kurulması zorunlu kılınmıştır. Aynı komite, diğer şirketler için de denetçinin gerekli görüp yönetim kuruluna bildirmesi halinde kurulmaktadır. $\mathrm{Bu}$ madde, kurumsal yönetime yönelik önemli bir uygulamanın hayata geçirilmesini sağlarken iç denetim birimlerine de yeni roller yüklemektedir. İç denetim birimleri, risklerin teşhis edilmesine yönelik olarak en uygun verilere sahip olan ve ayn zamanda bu verilerin nasıl yorumlanması gerektiği bilgisine sahip olan birim olarak komiteye önemli katkılar sunacaktır. Anket bulgularından elde edilen sonuçlar bu görüşü desteklemektedir.

Türkiye'de faaliyet göstermekte olan iç denetçiler, gerek denetim komiteleri aracilığıyla, gerekse de doğrudan ilgili komite ve kurullara destek olarak kurumsal

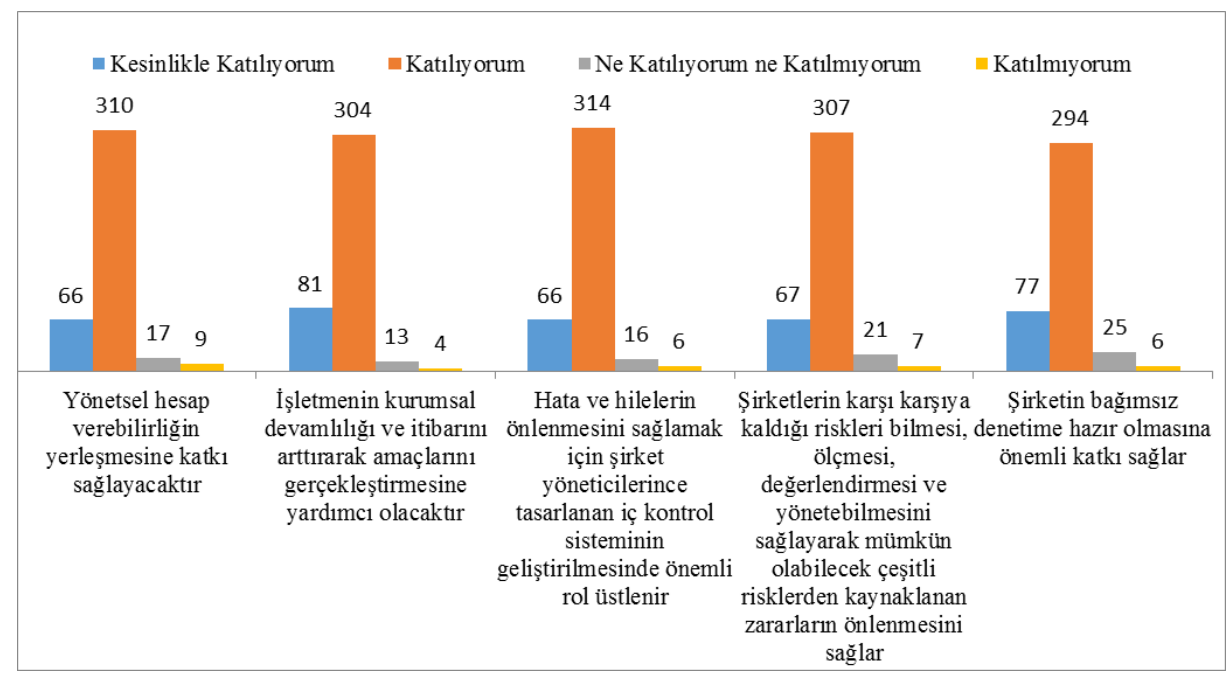

Şekil 2. Kurumsal Yönetim ile Ilgili Anket Bulgularının Genel Görüntüsü

yönetimin işletme içerisinde benimsenmesine önemli destek sunmaktadırlar. Şekil 2'deki toplu anket sonuçlarından, iç denetim mesleği mensuplarının, kurumsal yönetime ilişkin görevlere yönelik aktif rol üstlenme sorumluluğunun farkında olduğu anlaşılmaktadır. İç denetim birimi mensupları, kendilerini üst yönetim ve komiteler arasında bir köprü olarak görmekte ve kurumsal yönetim yapısının sağlamlaşmasına katkıda bulunmaktadır. Özellikle kurumsal yönetim açısından olmazsa olmaz konumda bulunan işletme içi kurullar ve örgüt kademeleri arasın- daki dengenin sağlanmasında iç denetim birimleri önemli katkı sağlayabilecektir. İç denetim birimi ve iç denetçilerin denge rolünü üstlenebilmesini sağlayan en önemli özellikleri, kurum içerisindeki tarafsızlık ve şeffaflıklarıdır. Görevlerini ve üstlendiği sorumlulukları etkin bir şekilde yerine getirebilmesi için, işletme içerisindeki tüm birimlere karşı şeffaf ve aynı mesafede bulunmak zorundadır. Bu haliyle iç denetim birimi, kurumsal yönetimin işletme içerisindeki en önemli garantörü olarak aktif rol üstlenmektedir. 


\section{Sonuç ve Gelecek Çalışmalar İçin Öneriler}

$\mathrm{Bu}$ çalışma ile Türkiyede faaliyet göstermekte olan iç denetçilerin, TTK sonrasında iç denetim mesleğini etkileyen pozitif dönüşümlerin farkında ve bu dönüşümleri hayata geçirmek üzere hazır oldukları sonucuna ulaşılmıştır. Türkiye'de iç denetçiler, işletmenin tüm yapıları ile temas halinde bulunarak hem paydaşların beklentilerini karşılamak açısından bir denge rolü hem de üst yönetimin stratejik konulara ilişkin bakış açısını genişletmek açısından bir danışmanlık rolü üstlenmelidir. TTK sonrasında, ilgili birçok maddede yönetim kuruluna yüklenen sorumluluklar sonucunda, işletme yönetimlerinin iç denetime olan ihtiyaçları artmıştır. Bu ihtiyacın amacına uygun olarak karşılanabilmesi, ancak iç denetim birimlerinde uzman meslek mensuplarının yer alması sonucunda gerçekleşebilecektir. İşletme yönetimlerinin, sahip oldukları profesyonel iç denetim kadrolarının bilgi ve tecrübesinden yararlanabilmek adına, iç denetçilere gerekli yetki ve sorumlulukları vermesi gerekmektedir.

Araştırmamız sonuçlarında da açıkça ortaya çıktığ1 üzere, Türkiyedeki birçok işletme için en önemli gelişim alanlarından biri olan kurumsal yönetim gibi konularda, iç denetçilerin çok önemli katkıları bulunabilecektir. İşletme yönetimlerinin bu potansiyelden yararlanması gerekmektedir. Ancak iç denetim biriminin, işletme içerisinde kurumsal yönetim ve diğer konularda yönlendirici bir rol üstlenebilmesi için kurum içi bağımsızlığının temin edilmesi gerekmektedir. İç denetim birimlerinin kurum içi bağımsızlığının en önemli sağlayıcısı denetim komitesidir.

TTK ile birlikte sayıları artan denetim komitelerinin tüm işletmelere yayılması gerekmektedir. Kurum içerisindeki etik dışı davranışları ve yolsuzlukları ortaya çıkarabilme adına denetim komiteleri, iç denetim birimlerine çok önemli bir çalışma özgürlüğü sunacaktır. Doğrudan denetim komitesine raporlama yapan bir iç denetim biriminin, kurum içi hiyerarşiden arınarak işletme ve paydaşları lehine çalışmalarını sürdürebilmesi mümkün hale gelecektir.

$\mathrm{Bu}$ çalışmada odak olarak iç denetim mesleği mensupları alınmışken gelecek çalışmalarda iç denetim birimi paydaşları odak alınarak paydaşların iç denetim mesleğinin gelişimine yönelik algıları ortaya konabilir. Çalışma içerisinde de sıklıkla belirtilen denetim komiteleri ve iç denetim birimi ilişkisi de daha kapsamlı olarak irdelenerek bu ilişkinin etkinliğine yönelik çalışmalar, literatürdeki tartışmaların zenginleşmesini sağlayacaktır. Ayrıca, iç denetim mesleğine yönelik uluslararası gelişmeler de dikkate alınarak Uluslararası İç Denetim Standartları̉na uyum ve mesleki sertifikasyonların etkisine yönelik araştırmalar, iç denetim literatürüne önemli katkılar sunabilecektir.

\section{Kaynakça}

Açıalın, İ. (2011). Yeni Türk Türk Ticaret Kanunu’nda Kurumsal Yönetimin Yeri. KPMG Gündem, 6, s.1315.

Bailey, A. J. (2010). The IIA's Global Internal Audit Survey: A Component of the CBOK Study-Core Competencies for Today's Internal Auditor. Florida: The Institute of Internal Auditors Research Foundation.

Bolger, D. (2010). A Call to Action: Stakeholders' Perspectives on Internal Auditing. Florida: The Institute of Internal Auditors Research Foundation.

Cömert, N. (2008). Türk Ticaret Kanunu Tasarısı Kapsamında İç Denetim ve İç Kontrol. İç Denetim Dergisi, 21, http://www.icdenetimdergisi.org, Erişim Tarihi: 06.06.2013.

Doğan, M. (2007). Kurumsal Yönetim. Ankara: Siyasal Yayınevi.

E\&Y. (2012). The Future of Internal Audit is Now: Increasing Relevance by Turning Risk into Results. Ernst\&Young, July, s.2-18, http://www.ey.com/Publication/, Erişim Tarihi:16.08.2013.

Eşkazan, A. R. (2005). Yeni Yasal Düzenlemeler Işı̆̆ı̆nda İç Denetim. www.icdenetimmerkezi.com, Erişim Tarihi: 30.09.2013.

Güreli, H. (2011). Yeni Türk Ticaret Kanunu Büyük Değişim Sürecinde Kurumsal Yönetim. İç Kontrol, İç Denetim ve Risk Yönetimi, İstanbul: Güreli Yayınları. 
Hatunoğlu, Z., Güneş N. (2012). Kurumsal Yönetim Uygulamalarının Muhasebe Bilgi Sistemine Etkileri. II. Bölgesel Sorunlar ve Türkiye Sempozyumu, 1-2 Ekim 2012, s.417-244.

Holzinger, G. A. (2013). Time to Seize the OpportunityGlobal Report. A.B.D: Audit Executive Center of The Institute of Internal Auditors.

İbiş, C., Çatıkkaş Ö. (2012). İşletmelerde İç Kontrol Sistemine Genel Bakış. Sayıștay Dergisi, 85, s.95121.

İDM (İç Denetim Merkezi). (2012). Yeni TTK İç Denetim ve Risk Yönetimi Madde ve Gerekçeleri. İç Denetim Merkezi, www.icdenetimmerkezi.com, Erişim Tarihi: 03.10.2013.

Karaege, Ö. (2012). Yeni Türk Ticaret Kanunu Çerçevesinde Yönetim Kurulu Üyeliğine Seçilme Koşulları. Gazi Üni. Hukuk Fak. Dergisi, 16 (3), s.67-94.

KYBP Kurumsal Yönetim Bilgi Platformu (2002), Kurumsal Yönetim Nedir ve İlkeleri Nelerdir? http://www.yenittk.com/tr/kurumsal-yonetim-kurumsal-yonetim-genel-bilgiler-kurumsalyonetime-iliskin-genel-bilgiler.html, Erişim Tarihi: 16.09.2013.

OECD. (2004). OECD Principles of Corporate Governance. Paris: OECD Publications.

Öz, E., Yağdır, S. (2012). UFRS Dönüşümünde İç Denetimin Etkisi ve Önemi. KPMG Gündem, s.8082,https://www.kpmg.com/TR/tr/Issues-AndInsights/Sayfalar/KPMG-Gundem.aspx,Erişim Tarihi: 12.08.2013.
PWC. (2012a). Aligning Internal Audit: Are You on the Right Floor?. 2012 State of the Internal Audit Study,http://download.pwc.com/ie/pubs/2012, Erişim Tarihi: 16.07.2013.

PWC. (2012b). Internal Audit 2012: A study Examining the Future of Internal Auditing and the Potential Decline of a Controls-Centric Approach. United States: PricewaterhouseCoopers.

SPK (Sermaye Piyasası Kurulu). (2005). Kurumsal Yönetim Illkeleri. Sermaye Piyasası Kurulu, Ankara.

TKYD (Türkiye Kurumsal Yönetim Derneği) (2005). OECD Kurumsal Yönetim İlkeleri 2004. Yayın No: KYD-Y/2005-01-01, İstanbul: Kurumsal Yönetim Derneği Yayınları.

TKYD (Türkiye Kurumsal Yönetim Derneği), Deloitte. (2006). Nedir Bu Kurumsal Yönetim?. Deloitte Kurumsal Yönetim Serisi, http://www.tkyd.org, Erişim Tarihi: 08.10.2013.

Ülgen, H., Mirze, S.K. (2010). İşletmelerde Stratejik Yönetim. 5. Baskı, İstanbul: Beta Yayınları.

Uzun, A.K. (2011). Değişime Hazır Mısınız?. TTK İş Geliştirme Bülteni, Deloitte, Aralık, http://www. verginet.net/Dokumanlar/2014/Genel-KurulToplantilari-TTK-Bulteni.pdf, Erişim Tarihi: 03.10.2013. 